\title{
Jean-Jacques Rousseau entre uma poética da superfície e a ideia de infância
}

Marlene de Souza Dozol

\begin{abstract}
Resumo
0 propósito desse ensaio é o de indicar o entrelaçamento operado por Jean-Jacques Rousseau entre filosofia, literatura e pintura em alguns de seus escritos para estabelecer um gênero de poética que, entre outras impressões, sugere os princípios estéticos para a compreensão e a condução da infância. Noutras palavras, trata-se de examinar se Rousseau - ao nos oferecer uma experiência ao mesmo tempo intelectual, sensível e plástica de certos conceitos - sugere os elementos basilares para a criação de uma pedagogia que alie o inteligível ao sensível em seu modo de teorizar e de atuar sobre crianças. A fim de ilustrar essa possibilidade, tomo aqui passagens de Júlia ou a nova Heloísa, de Os devaneios do caminhante solitário e breves remissões ao Emílio, a serem examinadas mediante dois artifícios heurísticos, a saber: o elogio de Eros feito por Agatão no "Banquete" (Platão) e o quadro "0 embarque para a ilha de Citera", do pintor francês Antoine Watteau. 0 texto conclui por uma poética da superfície, ao mesmo tempo formativa e formada, uma vez que interpela e se deixa fabricar por aquele que a sente e a pensa.
\end{abstract}

\section{Palavras-chave}

Estética - Formação - Pedagogia - Infância. 


\title{
Jean-Jacques Rousseau between a poetics of the surface and the idea of childhood
}

Marlene de Souza Dozol'

\begin{abstract}
This essay aims to indicate the intertwinement operated by JeanJacques Rousseau of philosophy, literature and painting in some of his writings to establish a genre of poetics which, among other impressions, suggests the aesthetic principles for understanding and conducting childhood. In other words, it examines whether Rousseau - by offering us a simultaneously intellectual, sensitive and plastic experience of certain concepts - suggests the basic elements for creating a pedagogy which combines the intelligible and the sensible in its way of theorizing and working on children. To illustrate this possibility, I take passages from Julie, or the New Heloise and Reveries of the Solitary Walker, as well as brief references to Emile and examine them by means of two different heuristic devices, namely: the praise of Eros expressed by Agathon in The Banquet, by Plato, and the painting "The Embarkation for Cythera", by French painter Antoine Watteau. The text concludes that there is a poetics of the surface, which is simultaneously formative and formed, as it challenges and lets itself be manufactured by the one who feels it and thinks about it.
\end{abstract}

\section{Keywords}

Aesthetics - Education - Pedagogy - Childhood.

I- Universidade Federal de

Santa Catarina, Florianópolis,

SC, Brasil.

Contato: lena.dozol@uol.com.br 
E se quiséssemos saber sobre o feitio do Eros que encontramos sobrevoando, aqui e ali, a escrita de Jean-Jacques Rousseau - na paisagem, nos passeios, no jardim, nos cômodos da casa, na "montagem" de suas figuras femininas, numa conversa ou refeição conjunta, numa ilha, numa planta - para daí extrairmos princípios para uma formação estética ou, mais precisamente, para o caso da pedagogia, um certo modo de conceber e conduzir a infância?

Em "O banquete", o poeta Agatão tece seu encômio a Eros mediante duas qualidades principais: a da beleza e a da virtude.

Para Agatão, o Deus do Amor é belo e jovem. Não age premido pela necessidade de mutilar ou violentar para alcançar seus intentos. Sua delicadeza e suavidade exigem finura para descrevê-lo. Marcha e repousa sobre as coisas mais tênues que há e vive entre as flores; é sobretudo ágil, capaz de envolver todas as almas e, flexível, nelas insinuar-se, entrando e saindo sem se fazer notado, dócil aos contornos do objeto que abarca. Não ignora as virtudes da justiça (pela qual se contrapõe à violência e fabrica o acordo voluntário), da coragem e da temperança, virtudes essas imprescindíveis para a aproximação e a paz entre os homens. Princípio e liame da sociedade, também sobrevoa as festas, as relações amenas e efêmeras, as danças e os sacrifícios. É também aquele que nos alivia em nossos trabalhos, temores, tristezas ou dor, porque é leve, alegre, não sente falta ou fome, não tem necessidades e compromissos com o trágico ou com a profundidade. Sábio, porque poeta, é também um "fazedor de poetas".

Em comentário a esse Eros infantil e esvoaçante de Agatão, José Américo Motta Pessanha, sem antes denunciar as filiações beletristas, carregadas e superficiais do discurso, diz que "O Eros pintado por Agatão nada tem da grandeza, da força, da imponência e da gravidade dos que foram apresentados pelos antecessores" (1995, p 95). Por todas as suas características, rege as relações de superfície, escreve o autor e, ao mesmo tempo, brinda-nos com uma graciosa imagem do Eros, que evoca, aos nossos olhos e ao nosso pensamento, todo o significado de sua composição: "o Eros de Agatão é um cupido de Watteau" (PESSANHA, 1995, p. 95), uma criança alada.

Esse elogio a Eros, feito pelo poeta e comentado por Pessanha, ao negar a conversão socrático-platônica - paradigma, por herança, de toda filosofia que se quer verdadeira -, parece inaugurar o que venho chamando de "poética da superfície". Talvez porque visceralmente ligada à experiência do instante e ao amor pelas coisas visíveis ou tangíveis.

Em que medida esse tipo de experiência e esse gênero de amor formam ou são formados pela inteligência e pela sensibilidade de quem os experimenta? Seria possível algum ponto de intersecção entre uma poética que evola da superfície ou da aparência das coisas e certa dimensão conceitual, (auto)formativa ou até mesmo pedagógica?

Para responder a essa questão, apostemos, antes, no prolongamento, operado por JeanJacques Rousseau, entre filosofia, literatura e pintura, fazendo desaparecer, em alguns de seus escritos, as fronteiras que delimitam tais gêneros ${ }^{1}$. A intenção aqui é a de primeiramente examinar a constituição de uma tal poética de um ponto de vista predominantemente estético para, paralelamente, indicar seu alcance formativo em sentido amplo - e pedagógico, já que se trata também de alcançar as premissas estéticas que levaram Rousseau a conceber a infância do modo como a concebeu: como "o sono da razão" (1999, p. 138); como etapa singular, de importância vital no processo de desenvolvimento humano e, por essa razão, dotada de um valor e de uma beleza em si mesma.

Passemos, então, ao delineamento da modalidade poética pretendida e dos expedientes usados pelo autor para expressá-la.

Formulemos mais uma vez a pergunta: assim como em Agatão, haveria também em

1- Em seu livro A retórica de Rousseau, Bento Prado Júnior trata do prolongamento operado por Rousseau entre filosofia e literatura, atribuindo uma centralidade para a música como paradigma de escrita. Aqui, acrescento a pintura como mais uma referência a ser explorada em letras rousseaunianas. 
Rousseau uma “poética da superfície”? Uma poética escondida atrás da ideia que ele nos dá a conhecer desde o seu Primeiro discurso e que nos causa admiração até hoje, qual seja, a de que a reflexão cansa e entristece o homem? Se sim, por quais artifícios de linguagem o filósofo-artista daria conta de tal poética? Em que momentos específicos sua escrita sobre o instante, paisagens, coisas e crianças também se deixa sobrevoar por "um cupido de Watteau"?

Detenhamo-nos um pouco nessa última questão. É ela que irá sugerir as pistas para ampliar o já anunciado prolongamento entre os gêneros filosófico e literário operado pelo teórico-artista. Trata-se de, em meio a ambos os gêneros, introduzir uma matriz pictórica em seus escritos. Noutras palavras, em que medida o pensamento, a prosa poética (adubada pelo fato de os sentimentos e a subjetividade despontarem como campo semântico emergente na transição do século XVII para o século no qual viveu Jean-Jacques) e a imagem pictórica corroboram uma mesma força e um mesmo espaço de escritura? Voltemos à questão imediatamente anterior.

Por que um "cupido de Watteau"? 0 que teria levado Pessanha a condensar o dito elogio de Agatão nessa imagem e o que ela nos revela sobre certos escritos rousseaunianos, fruídos da perspectiva de um Eros que "marcha e repousa sobre as cousas mais tênues que há, e aí faz sua casa"? (PLATÃO, 1971, p. 154).

Se em "O banquete" podemos encontrar os indícios de natureza literária para pensar uma "poética da superfície" em Rousseau, num ensaio de Norbert Elias sobre o quadro "O embarque para a ilha de Citera", de Antoine Watteau (pintor francês que viveu de 1684 a 1721), encontramos - ainda que consideremos as distâncias significativas entre Rousseau e Watteau - os de ordem pictórica.

Nessa obra,

vê-se o cortejo dos casais de amantes que, naquele exato momento, começam a se preparar para percorrer o caminho até a praia, sempre acompanhados por cupidos que parecem doar ao quadro uma atmosfera alegre e festiva. Lá os espera o barco paramentado que, logo, os levará à ilha de Citera (ELIAS, 2005, p. 20),

conhecida pelo imaginário já do século XVII como "a ilha do amor". Sob as preceptivas da sociedade de corte, a natureza campestre, na forma de paisagem, recebe, dentre outras coisas, uma "leveza graciosa" (ELIAS, 2005, p. 12), representada por pequenas figuras que se movimentam à vontade e têm atrás de si um grande e exuberante jardim natural "limitado por altas árvores com suas copas verde-escuras" (ELIAS, 2005, p. 20-21). Embora se assemelhe a um fundo de palco no qual uma peça está sendo representada, está ausente toda teatralidade, escreve Elias.

$\mathrm{Na}$ apreciação crítica da obra por Jules e Edmond Gouncourt (encontrada no apêndice "Seleção de textos sobre Watteau", na mesma edição do ensaio de Elias), lê-se:

Watteau renovou a graça. A graça, nele, não é mais a graça antiga: um encanto rigoroso e sólido, a perfeição de mármore de galatéia, a sedução toda plástica e glória material de Vênus. A graça de Watteau é a graça. Ela é o nada que veste a mulher com um ornamento, uma frivolidade, um belo para além do belo físico. Ela é coisa sutil que reflete o sorriso da linha, a alma da forma, a fisionomia espiritual da matéria. (2005, p. 65)

Na busca de um sentido para a "graça" - por oposição ao "risível" -, Bergson também procurou defini-la e nos ajuda a capturá-la tanto num quadro de Watteau como em qualquer outra obra que a acolha como uma categoria de beleza:

(...) Em toda forma humana (nossa imaginação) percebe o esforço de uma alma que modela a matéria, alma infinitamente ligeira, eternamente móvel, subtraída à 
pesadez, porque não é a terra que a atrai. De sua ligeireza alada esta alma comunica qualquer coisa ao corpo que ela anima. A imaterialidade que passa, assim, para a matéria, é o que se chama a graça (...). (BERGSON, apud SUASSUNA, 2011, p. 159).

0 que vemos no quadro de Watteau é uma graça em movimento, não só porque assim se dá aos nossos olhos, mas também porque é capaz de sugerir "estados de alma”, por meio de uma técnica primorosa de doar uma "fisionomia espiritual” para a matéria, esboçada por traços de uma "alegria delicada" (ELIAS, 2005, p. 65) de par com uma "suave melancolia" (ELIAS, 2005, p. 55). Importante notar que essa sugestão é laboriosamente produzida por um paradigma musical de pintura: é o sobe e desce da linha curva do quadro, com seus pontos altos e baixos e com suas quebras de ritmo, que, de certa maneira, faz-nos "ouvir música" quando o contemplamos.

Segundo Theóphile Gautier, trata-se de uma pintura séria sob a capa e as cores do frívolo, de galantes casais jovens, dos fugazes movimentos femininos e das saias de seus vestidos, de "crianças-cupido [que] esvoaçam, rodopiam e brincam (...)” (2005, p. 71), escondendo, quem sabe, a dor do seu próprio criador: Watteau provinha das classes inferiores, afastava-se voluntariamente da sociedade dos homens, vivia retraído, era enfermiço e, sim, melancólico, alheio aos prazeres ruidosos e às muitas festas da corte parisiense nos primeiros anos da regência de Felipe de Orléans, após a morte de Luís XIV.

0 quadro foi entregue à Academia Real em 1717 e, 33 anos depois, Jean-Jacques Rousseau escreveria o Discurso sobre as ciências e as artes.

Sabemos o quanto Rousseau personificou do ataque à estética rococó e da oposição ao gosto palaciano pela ostentação, propondo, segundo Arnold Hauser, “(...) o ideal de simplicidade e a sobriedade de uma visão puritana da vida (...)" (1995, p. 498), com o qual nos deparamos em Júlia ou a nova Heloisa ou em certas passagens de Os devaneios do caminhante solitário. Também não ignoramos a diferença entre a melancolia e o bucolismo da pintura de Watteau - a qual expressa uma parceria requintada e amaneirada entre a natureza e a cultura ${ }^{2}$ - e a radicalidade, o modo de pensar plebeu e irreverente de Rousseau, somados ao seu genuíno anseio pelo estado de natureza desdobrado em uma utopia educativa e, sobretudo, política.

Mas há uma chave para que pensemos um tímido cruzamento entre a pintura de um e a escrita de outro: ambos dominam a arte de criar uma atmosfera de tons melancólicos e líricos que permite ao expectador projetar-se na obra, produzindo, ainda que em contextos ou perspectivas ideológicas diferenciadas, efeitos semelhantes.

Aqui e ali, no quadro e em escritos como Júlia ou a nova Heloisa e Os devaneios do caminhante solitário, as manobras de um "fazer" ou um "fabricar" encontram-se à espreita de um expectador-leitor mais ou menos avisado. Mas, antes de passarmos à comparações da ordem dos detalhes ou dos pequenos e delicados arranjos que se encontram no interior dos escritos rousseaunianos, vejamos alguns comentários de natureza mais abrangente a respeito dos dois artistas em foco.

Tanto na pintura de Watteau quanto na prosa filosófico-literária deRousseau, desaparece a tendência barroca para o monumental, o cerimonioso e o solene. Já não encontramos, no primeiro, a expressão de poder e de grandeza encontrada nos gêneros cerimoniais, na pintura religiosa e nos enormes quadros históricos: em lugar da paisagem heroica, o cenário idílico da pintura bucólica. Já no romance do segundo, está ausente o heroísmo típico de semideuses ou super-homens: seus heróis aproximam-se do homem comum; não são anjos, têm corpo e sabem disso; ainda assim, escolhem o dever em lugar das paixões, de acordo com o sentimento

2- Embora, e em alguns aspectos, diferencie-se do convencionalismo da pintura de um Boucher (1703-1770), por exemplo 
e a moral virtuosa em voga nos tratados e nos romances da época.

0 subjetivismo, que ainda hoje domina nossa concepção de arte, é uma marca da pintura de Watteau (e de sua recepção) e, de maneira análoga, das linhas escritas pelo autor da $A$ nova Heloisa e de Os devaneios. Não se trata mais de impressionar ou dominar e sim de seduzir e encantar.

Em termos de efeitos, a melancolia em Watteau e em Rousseau é (nem tão obviamente assim) diferente, porque ligada a utopias sociais distintas: numa, a natureza aparece como um lócus/cenário para um encontro entre natureza e uma civilização requintada, hedonista e sensual, em contornos e cores da cidade e da corte parisiense; noutra, essa mesma natureza-paisagem (porém moralizada) e a consciência do homem - reservatório inato de bondade e virtual em termos sociais - escoam como uma e mesma coisa, na direção de mudar os rumos da própria história (Contrato social) ou, se isso não for possível, da vida comunitária e doméstica (A nova Heloisa) ou ainda da perspectiva individual (Emílio).

Contudo, no que toca a uma espécie de energia impressionista que se desprende da pintura e das letras em exame, ambas parecem brotar de uma mesma nascente: refiro-me aqui à nostalgia de um paraíso perdido. Pode-se dizer até que há um mesmo problema filosófico que as permeia, qual seja, o da validade da cultura humana frente à natureza e ao seu significado mais misterioso e profundo.

As palavras de Hauser - mesmo que esse autor não reconheça, textualmente, afinidades entre ambas as obras (HAUSER, 1995, p. 511) - acabam por sugerir as pegadas para que vislumbremos essa aproximação:

A profundidade de sua arte [de Watteau] deve-se à ambivalência de seu relacionamento com o mundo, à expressão tanto da promessa quanto da inadequação da vida, ao onipresente sentimento de uma perda inexprimível e de uma meta inalcançável, à consciência de uma pátria perdida e do caráter utópico e remoto da verdadeira felicidade. (HAUSER, 1995, p. 511).

Diz o autor, ainda, que a pintura de Watteau é o resultado da mistura de pessimismo e otimismo, de tédio e de alegria que caracterizou a personalidade do pintor e que, por fim, a realização da obra do maior intérprete da nova arte francesa surgida na Regência contou com condições prévias: o conflito latente entre cidade e campo e o sentimento de mal-estar com a civilização (HAUSER, 1995, p. 573). A propósito desse mal-estar - antes e principalmente a partir de Rousseau -, o próprio Hauser escreve:

(...) a nostalgia da natureza enquanto fuga do convencionalismo tinha atrás de si uma longa história. Como sabemos, aparecera repetidamente na forma de poesia bucólica no auge das culturas urbana e palaciana (...). (1995, p. 561).

E mais adiante:

0 primitivismo de Rousseau não passava de uma variante do ideal arcádico e uma forma daqueles sonhos de redenção que se encontram em todas as culturas exauridas, mas em Rousseau esse sentimento de "desconforto com a cultura" que tantas gerações antes dele tinham sentido tornou-se consciente pela primeira vez, e também foi ele o primeiro a desenvolver uma filosofia da história a partir dessa fadiga cultural. (1995, p. 570).

Essa distinção feita a Rousseau não nos obriga a subtrair as condições prévias e o sentimento supracitados de suas motivações, traduzidas, de modo dramático, na tensão entre natureza e civilização ou natureza e história. Tanto A nova Heloísa como Os devaneios (bem como o resto de seus escritos) as pressupõem.

Feitos os comentários de ordem mais abrangente, passemos, com mais vagar, aos 
escritos de Rousseau mediante o prolongamento e as afinidades entre filosofia, literatura e pintura. No romance epistolar Júlia ou a nova Heloísa, Rousseau nos mostra o seu extraordinário talento para expor seu pensamento mediante um arranjo ritmado e imagético de palavras. Segundo Fúlvia Moretto, A nova Heloísa é o romance do pensamento do autor "que suas obras iriam teorizar, mas é também o romance de sua sensibilidade e de seu lirismo" (1994,pp. 18-19) e "a grande preocupação de Rousseau ao redigir $A$ nova Heloísa foi a melodia da frase, a beleza do ritmo, [...]. Procura a harmonia dos sons, a cadência, tentando aproximar-se da frase musical, inaugurando assim a prosa poética" (1994, p. 17). E, mais, continua a autora: "Procura, além disso, a imagem nova e surpreendente, a metáfora ou a comparação inesperadas" (1994, p. 17). Acrescente-se ainda a alegoria, sem necessariamente passar pela clareza do conceito, mas, de certa forma, aludindo a ele. Detenhamo-nos brevemente nesse último ponto para apreendermos o modo de fazer uma prosa poética que toma a superfície não só como manifestação de uma espécie de beleza mas também como fonte legítima de um pensamento filosófico-educacional e pedagógico.

Se compararmos o "Eliseu" ${ }^{3}$ - jardim à moda inglesa cultivado por Júlia junto à residência dos Wolmar (expressão paisagística de um feliz enlace entre natureza e cultura) em oposição ao jardim clássico francês (de linhas retas, rígido e geométrico) - e o conceito de “educação negativa” que Rousseau irá nos apresentar sob a forma de uma conversa entre Saint-Preux, Júlia e M. de Wolmar a respeito da educação dos filhos do casal ${ }^{4}$, veremos que o jardim inglês bem pode ser visto como uma alegoria sensível e filosóficoeducacional do referido conceito. A julgar por essa imagem - a do jardim inglês - e por esse conceito polêmico em termos de sua recepção, tanto pelos contemporâneos de

3- Descrito na Carta XI da quarta parte do romance.

4 - Apresentado na Carta III da quinta parte.
Rousseau como ainda nos dias de hoje - o de "educação negativa" ou de uma aparente “não educação” -, ler Rousseau significa, por vezes, passar por uma experiência intelectual, sensível e visual do próprio conceito. Assim como o jardim inglês, a educação aos moldes rousseaunianos obedece a uma fórmula de intricada combinação entre características perfeitamente naturais - as da criança, arquétipo do homem natural - e inteiramente superficiais, relativas ao conjunto de artifícios pedagógicos que deverão orientar sua educação, mas que não devem aparecer.

0 artifício, nesse caso, encontra-se a serviço de uma paisagem formativa ou pedagógica bastante peculiar: aquela que, se não ignora as potências naturais, admite simultaneamente as recorrências da arte.

$\mathrm{Na}$ perspectiva da poética e do prolongamento ou das afinidades que estou tratando aqui, fragmentos da descrição do "Eliseu" remetem muito sutilmente ao discurso retórico de Agatão sobre Eros e aos cupidos de Watteau que, em versão rousseauniana, assumem a forma de passarinhos e, por vezes, de crianças, como mostrarei mais adiante ao comentar outro de seus escritos. Continuemos, pois, a explorá-la por meio dos pequenos e delicados arranjos de Jean-Jacques.

Plasticamente, o "Eliseu" não corresponde ao estilo das paisagens-cenários de Watteau, mas igualmente celebra a beleza e a graça da vida, buscando seduzir, mediante a criação daquela atmosfera, o expectador-leitor.

Iniciemos com as primeiras impressões de Saint-Preux no passeio que faz em companhia dos donos da casa:

Ao entrar nesse pretenso pomar, senti-me atingido por uma agradável sensação de frescor que obscuras sombras, uma verdura animada e viva, flores esparsas por todos os lados, um murmúrio de água corrente e o canto de mil pássaros trouxeram à minha imaginação pelo menos tanto quanto aos meus sentidos; (...) (ROUSSEAU, 1994, p. 410). 


\section{E prossegue:}

Todos esses pequenos caminhos eram ladeados e atravessados por uma água límpida e clara, que ora circulava entre a relva e as flores em fios quase imperceptiveis, ora em riachos maiores que corriam sobre um cascalho puro e matizado que tornava a água mais brilhante. Viam-se fontes borbulharem e sair da terra e algumas vezes canais mais profundos nos quais a água calma e tranquila refletia os objetos a olho nu. (ROUSSEAU, 1994, p. 412).

A essa faculdade produtora de imagens visuais através da escrita soma-se a habilidade de Rousseau de, gradativamente, ir dando um tom ou espírito ao texto ${ }^{5}$.

0 jardim vai sendo descrito pela reunião de uma pletora de verdes e flores que, filtrada pelas retinas de Saint-Preux, provocam-lhe um estado de alma que se associa ao desejo do devaneio. Agora, é o próprio Saint-Preux que tem, dentro de si, um Eros delicado, que lhe concede "um andar suave, cômodo e seco sobre uma espuma fina sem areia, sem erva e sem rebentos ásperos" (ROUSSEAU, 1994, p. 411).

0 "jardim-superfície" alia-se ao sentimento íntimo de uma natureza que reedita o asilo ancestral, uma mítica natureza-mãe que acolhe seu filho e o deixa repousar:

Mais percorria esse agradável asilo mais sentia a sensação deliciosa que experimentara ao entrar; contudo, a curiosidade mantinha-me com a atenção suspensa: tinha mais vontade de ver as coisas do que examinar suas impressões e gostava de entregar-me a essa encantadora contemplação sem ter o trabalho de pensar (ROUSSEAU, 1994, p. 413).

5- De acordo com Alfredo Bosi, o termo tom, que na linguagem da música adquiriu um sentido preciso, e até matemático (tons maiores e menores), designa em literatura as "modalidades afetivas da expressão" (1988, p. 279)
A entrega de Saint-Preux é, se não contida, adiada pela Sra. de Wolmar, que alerta o ex-amante:

(...) tudo o que vedes é apenas a natureza vegetal e inanimada e faça-se o que se fizer, ela deixa sempre uma ideia de solidão que entristece. Vinde vê-la animada e sensível. É lá que, a cada momento do dia, encontrareis nela um atrativo novo. (ROUSSEAU, 1994, p. 413).

Júlia refere-se a um espaço-viveiro no qual pássaros em quantidade vivem em liberdade e são discretamente mantidos pela quase invisível reprodução artificial de condições naturais favoráveis a sua permanência no jardim:

Eram os arvoredos desse outeiro que serviam de asilo a essa multidão de pássaros cujo chilreio ouvira de longe e era à sombra dessa folhagem, como sob um grande guarda-sol, que os víamos esvoaçar, correr, cantar, provocarem-se, baterem-se, como se não tivessem percebido. (ROUSSEAU, 1994, p. 413).

Rousseau entremeia o receio de Júlia com a "solidão que entristece" a "passarinhos-crianças" que devolvem aos "olhos-alma" a alegria delicada dos chilreios e dos graciosos movimentos.

Essa "cena-quadro" remete a uma passagem da "Nona caminhada" de Os devaneios do caminhante solitário, na qual Rousseau, assaltado pelas sombras do "complô universal" que urdiram contra a sua pessoa ${ }^{6}$ e desertor da própria utopia de felicidade coletiva que outrora projetara, procura consolo e descansa ao olhar crianças que fortuitamente cruzam o seu caminho:

Pois não creio que alguma vez um homem tenha gostado mais do que eu de ver

6- É preciso considerar aqui a perseguição, ao mesmo tempo real e imaginária, sofrida por Rousseau da parte de seus contemporâneos em função de seus escritos e do seu modo de ser. 
pequerruchos folgar e brincar juntos e, muitas vezes, na rua e nas caminhadas, detenho-me para olhar suas travessuras e suas brincadeirinhas, com um interesse que não vejo em mais ninguém. (ROUSSEAU, 1995, p. 118).

0 que se observa em "escritas-paisagens" rousseaunianas é uma alternância a modular os estados de alma do leitor-expectador. Sua escrita por vezes solar, por vezes assaltada por sombras, intercalada por claros e escuros, é compreensível, para o caso de Saint-Preux, pelo conflito que anima o romance: o amor impossível entre um homem e uma mulher de classes sociais distintas. Ao terminar a carta, Saint-Preux, contente com seu novo trabalho de alimentar os pássaros, escreve:

Hoje, levantei-me cedo e, com a pressa de uma criança, fui encerrar-me na Ilha deserta. Quantos agradáveis pensamentos esperava levar para esse lugar solitário onde unicamente o doce aspecto da natureza devia expulsar de minha lembrança toda essa ordem social e factícia que me tornou tão infeliz! (ROUSSEAU, 1994, p. 422).

Vamos reencontrar, agora na "Quinta caminhada" de Os devaneios, esse mesmo doce aspecto da natureza misturado a um idêntico lamento. Lá, Rousseau amplia a paisagem. Não se trata mais de um jardim doméstico à moda inglesa, mas da natureza mesma, disposta numa pequena ilha, descrita a caneta e a pincel, na qual o velho filósofo foi feliz e lá permaneceria para o resto de sua vida não fosse a "maldade" dos homens.

A natureza relativamente exuberante, o convívio agradável e sem gravidade com os poucos habitantes da ilha, a delícia de deixar seus livros encaixotados, a substituição de “melancólicas papeladas" (ROUSSEAU, 1995, p. 73) por flores e fenos ${ }^{7}$, a resolução de herborizar, a simpatia que desperta em nós

7- Expressão de um dos paradoxos rousseaunianos: 0 de um escritor "contra" a escrita. quando nos faz imaginá-lo "empoleirado sobre grandes árvores, cingido por um saco que enchia de frutos e que fazia baixar em seguida ao chão por uma corda" (ROUSSEAU, 1995, p. 47), seus exercícios matinais e o bom humor daí advindo, seu deslizar em um pequeno barco na macia superfície do lago de Bienne, o banhar-se com a pureza e a transparência das águas (desejo que estendia às relações entre os homens), este Rousseau reconciliado com o paraíso sobre a terra é também aquele que se deixa capturar pelo complô. Rousseau, na Ilha de Saint-Pierre, é volta e meia assaltado pela sombra de seus perseguidores: lamenta o destino que lhe é imposto, manifesta seu receio quanto a um provável exílio na Inglaterra, deseja esquecer e ser esquecido, expõe a esperança vã de lá ficar para os restos dos seus dias e enlaçado a si mesmo.

E então, em busca de salvação, procura a "pele do mundo" para, uma outra vez, emergir e nela encontrar refúgio. Essa predisposição traduz, com um máximo de força poética, a experiência do mais genuíno sentimento da existência. Mas não é só. Ela está na raiz da tentativa engenhosa de Rousseau de produzir em que pesem os seus próprios argumentos em contrário - uma forma, digamos, "sensorial" de escrita (se isso não soar muito extravagante para nós). Para além da expressão da subjetividade complexa do autor, essa forma guarda e alimenta a ambição de propiciar ao leitor-expectador o fluxo da experiência - ainda que uma terceira experiência, já que a primeira pertence ao vivido e a segunda, a quem escreve esse mesmo vivido (STAROBINSKY, 1991) -, a ponto de querer que ambos, autor e leitor-expectador, sejam um só. Rousseau deseja, com paixão, ser compreendido, acolhido pelos outros e, para isso, usa as letras, a música e a pintura.

A ideia de uma escrita com o poder de vicejar no papel parece persegui-lo, acrescida às demais questões que lhe são caras: a relação entre linguagem e verdade, entre linguagem e sentimento, sua opacidade e sua transparência, o vínculo que estabelece entre o bom e o belo em ação. Por trás dessa obsessão há, sem 
dúvida, uma "estranha indústria", que junta sua teoria da linguagem, o paradigma musical como fonte indireta para escrever, as regras da retórica, a metáfora, a alegoria e a analogia, a imagem e o conceito.

Tudo isso como uma só e mesma coisa mental, ao fim e ao cabo? Em parte, sim, como já vimos. Talvez em proporção maior no artista que deliberadamente coloca sua técnica no encalço daquele que frui de sua arte, ou seja, o leitor-expectador.

Mas voltemos ao refúgio que Rousseau procura na ilha e que seus sentidos capturam em meio à natureza.

0 curioso é que esse refúgio não parece ser totalmente ou de uma vez por todas subordinado à evasão. Por vezes, é preciso agarrar-se à superfície e contar com a sua força sugestiva de mecanismos internos de autorregulação. É quando a repetição que lhe é inerente concorre para aquela porção de estabilidade que Rousseau precisa para estar, ainda que provisoriamente, em paz:

Quando a noite se aproximava, descia dos cumes da Ilha e ia de bom grado sentar-me à beira do lago, sobre a praia, em algum refúgio escondido; lá, o ruído das vagas e a agitação da água fixando meus sentidos e expulsando de minha alma qualquer outra agitação, a mergulhavam num devaneio delicioso, em que a noite me surpreendia muitas vezes sem que o tivesse percebido. 0 fluxo e o refluxo da água, seu ruído contínuo mas crescente por intervalos, atingindo sem repouso meus ouvidos e meus olhos, supriam os movimentos internos que o devaneio extinguia em mim e bastavam para me fazer sentir com prazer minha existência sem ter o trabalho de pensar. (ROUSSEAU, 1995, p. 75).

8- Para usar uma expressão de Paul Valéry, ao referir-se à construção até mesmo de um poema que, afinal de contas, procura reconstituir uma emoção e não dispensa, para isso, as manobras do pensamento (apud NOVAES, 1994, p. 11).
Rousseau, embalado por um movimento contínuo, como que aninhado à superfície, experimenta o presente como duração de si mesmo. Algo raro acontece ali (e em nós?), por obra de um certo tipo de disposição da parte de quem o sente (nesse sentido, a poética da superfície é formada por aquele que se deixa impressionar). Por outro lado, é essa mesma disposição que, aos poucos, vai sofrendo metamorfoses e de disposição passa a substância. É quando consciência e natureza se fundem. Rousseau chega assim e, enfım, a uma formulação não só filosófico-literária mas também imagética do sentimento da existência, possível quando a superfície o acolhe e vice-versa.

Fiel às suas bases sensualistas, Rousseau afırma que o ponto de partida são as disposições. Nem demasiada agitação e nem um repouso absoluto são recomendáveis para ativá-las, mas um meio-termo.

Mas onde pousar nossas disposições? Talvez naquilo que, para o nosso alento e sorte, sobrevoa e rege essa camada epidérmica do mundo e da vida na forma de um Eros de Agatão, escondido, em versão rousseauniana, na penúltima página da "Quinta caminhada": “(...) mas é também mais agradável quando leves e doces idéias, sem agitar o fundo da alma, apenas tocam levemente sua superfície" (ROUSSEAU, 1995, p. 75). Pode-se dizer até que Rousseau amplia o horizonte para o voo desse Eros e o convida a pousar, também, na pele da sua própria alma.

Eis aí um modo curioso de romper com as fronteiras entre o interior e o exterior, separados por obra de uma oposição formal que alimentou desde sempre uma espécie de hostilidade entre ambos, e reunificados, em Rousseau, sob a forma do devaneio.

0 rompimento de tais fronteiras, entretanto, não nos permite simplificar o devaneio a ponto de acreditar que a imagem ou a paisagem em si mesmas tenham a força de se confundirem com a nossa própria superfície. Antes, é preciso que toquem naquele algo de profundo que existe dentro de nós para, em 
seguida, subir à tona de outra maneira. Em contrapartida, se não atentarmos para o jogo também profundo das imagens ou paisagens da matéria - uma vez que são capazes de atingir profundezas -, não provaremos os efeitos desses lances recíprocos. Rousseau os prova, opera outra vez uma ruptura de fronteiras agora entre superfície e uma profundidade que dispensa a reflexão - e a expressa através de sofisticados recursos literários que lhe exigem um longo esforço de reconstrução.

Experimentaria a criança algo semelhante?

$\mathrm{Na}$ criança, segundo Rousseau, as sensações formam e as impressões afetam, mas não se transmutam em arte, no sentido corrente que damos a essa palavra. No máximo, começam e terminam na própria efemeridade do instante e preparam o gosto (assim como o intelecto e a moral). Podemos, todavia, tomar a imagem do sentimento de existência proposta por Rousseau como premissa para observar crianças - habitantes, por excelência, da superfície das coisas do mundo - e extrair daí uma pedagogia discreta, com o fim de permitir e proteger o fluxo da experiência e das impressões particularmente infantis.

Em meio à crianças, às coisas e ao espaço, podemos nos demorar um pouco mais sobre os fundamentos estéticos da pedagogia rousseauniana, notadamente o gosto de Rousseau pelo que, a princípio, não seria digno de atenção. Daí que uma "poética da superfície" referida a ele não poderia dispensar os detalhes, sua inclinação a dar importância a coisas menores ou aparentemente insignificantes e fazer delas um repouso, algo de relevante ou mesmo de belo. Penso que tal inclinação cumpriu - num século no qual a criança ainda era vista sob o signo de uma incompletude a ser superada mediante o aligeiramento do tempo - a função de atuar como uma pulsão vital de ordem estética a orientar o seu pensamento em relação à infância e extrair daí a pedagogia que nos dá a conhecer, em A nova Heloisa e que aprofunda no Emílio, seu tratado sobre a educação. Para além de suas convicções epistemológicas, éticas e políticas,
Rousseau "desenha" o menino com traços e cores que doam asas e graça à infância: basta imaginar a pequena figura de Emílio arriscando seus primeiros passos e, depois, correndo alegre e saudável pelos prados...

A superfície abriga, de fato, composições de minúcias e mimetismos que guardam em segredo uma pletora de infinitos e imensidões para aquele que sabe observar e devanear; não só pelo prazer da fruição mas também para extrair daí pensamento e arte, incluída aí uma linguagem que diz a infância e inspira o seu cuidado.

Bachelard, em A poética do espaço, refere-se a um "devaneio miniaturizante". Aceitemos, como um mimo, a sua lembrança de ter visto um jovem líquen nascer e estender-se sobre um muro para compreender a miniatura como "um exercício de frescor metafísico" e sua natureza repousante, "sem jamais fazer adormecer” (2008, p. 168). E, nesse exercício, ainda que exploremos a camada mais fina das imagens nascentes, prossegue o autor, não deixamos de sentir as vibrações profundas: as que produzem e as que produzimos.

Seria de outro matiz o devaneio do caminhante solitário após herborizar por montanhas, vales e bosques com suas grandes e pequenas florestas? 0 que ia Rousseau buscar lá e ali além de curiosas e raras espécimes vegetais para o seu herbário? Passemos, por fim, à "Sétima caminhada" de Os devaneios, na qual Rousseau nos dá a conhecer as suas atividades botânicas e seu apreço pelos pormenores.

Quando os velhos olhos de Rousseau pousam sobre uma folha reencontrada nos arredores de Paris, mais que a paixão pela minúcia, parece haver um desejo escondido de repouso e comunhão com algo maior.

Ao tratar do devaneio de um botânico, Bachelard afirma que "o minúsculo, porta estreita por excelência, abre o mundo" (2008, p. 164), é agente de imensidão (2008, p. 214). Rousseau, amante de vastas extensões e horizontes, sabia também chegar a elas por portas estreitas. 
As árvores, os arbustos e as plantas vestem e enfeitam a terra em meio a cursos de água e ao canto dos pássaros, propiciando ao contemplador um "devaneio doce e profundo" (ROUSSEAU, 1995, p. 93). E, através dos próprios sentidos, perde-se "na imensidade desse belo sistema” (ROUSSEAU, 1995, p. 93) com o qual se identifica. Contudo, essa imersão no todo contemplação da natureza como uma massa e em seu conjunto - recusa-lhe a graça dos objetos individuais em sua infınita variedade, partes desse mesmo "universo que se esforçava por abarcar” (ROUSSEAU, 1995, p. 93).

Fugindo dos homens - que outrora julgava seus irmãos, levando-o a projetar uma utopia política de felicidade terrena -, Rousseau encontra no interior de uma planta um alento. Bastam um estilete e uma lupa "para vagar descuidadamente de erva em erva, de planta em planta” não só para examiná-las, comparálas e classificá-las, mas sobretudo para acalmar suas próprias paixões e encontrar aquele asilo ancestral condensado em quase tudo que é pequeno e delicado:

Tomei gosto por essa recreação dos olhos que, no infortúnio, repousa, diverte, distrai o espírito e interrompe o sentimento das penas. A natureza dos objetos favorece muito essa divagação e a torna mais sedutora. Os odores suaves, as cores vivas, as mais elegantes formas parecem disputar à porfia o direito de fixar nossa atenção. (ROUSSEAU, 1995, p. 93).

Embrenhado nas verticalidades densas e prodigiosas da mata, o filósofo acha o que ela esconde de pequeno e gracioso para, em seguida, retornar à grande e velha floresta que lhe serve de escudo: "Parece-me que sob a sombra de uma floresta sou esquecido, livre e calmo como se não tivesse inimigos ou como se a folhagem dos bosques me defendesse de seus ataques..." (ROUSSEAU, 1995, p. 99).

A floresta e seus infinitos produzem assim um determinado estado de alma, ao mesmo tempo em que o regula, oferecendo ao filósofo-botânico a oportunidade de examinar as leis de pequenas e frágeis estruturas. Diante "de um espaço que não tem dramas a localizar" (BACHELARD, 1995, p. 222), Rousseau se deixa envolver pelo silêncio e faz lembrar Pierre Jean-Jouve, que ouve, num de seus poemas, uma "enorme e profunda camada de musgo, em gritos de veludo" (apud BACHELARD, 1995, p. 192). Chegamos assim a um certo tipo de habilidade literária em fabricar o que Bachelard chamou de "miniaturas sonoras". Vejamos em que medida ela aparece em Rousseau.

A imagem poética de Jean-Jouve não se aplica diretamente às imagens rousseaunianas encontradas na "Sétima caminhada" - compostas, em grande parte, por observações e relatos -, mas pode sugerir a sonorização que, por vezes, encontramos em seus textos. Rousseau também é mestre em fabricar o silêncio, condição indispensável para a escuta da natureza e de si mesmo. Sem ele, como imaginá-lo vagueando pelas florestas e bosques, inclinando-se para apanhar uma planta e depois dissecá-la, com vagar, para encantar a si próprio e amar ainda mais a natureza? Esse mimetismo com a vida em curso tem ainda, em sua forma literária, a pretensão de ser musicalizado: com Rousseau - jovem e cheio de vigor -, galgamos os rochedos, as montanhas com suas fendas, mergulhamos nos vales e bosques, alcançamos precipícios, ouvimos pássaros raros e provamos "o horror dessa solidão" (ROUSSEAU, 1995, p. 99) para, em seguida, devanearmos à beira de lagos ou "sobre almofadas de Lycopodium e de musgo" (ROUSSEAU, 1995, p. 99-100) e, mais tarde, repousarmos sobre a superfície de uma folha ou flor.

A expressão mais tarde merece nossa atenção.

Lembremos que Rousseau, na "Sétima caminhada”, é um homem de idade avançada para os padrões do século XVIII. Não está, pois, em condições de reeditar as antigas aventuras nas quais herborizara bastante bem. Mas, em seu momento atual, ao abrir seu herbário, transporta-se para elas: 
Todas as minhas caminhadas botânicas, as diversas impressões da localização dos objetos que me impressionaram, as idéias que me provocaram, os incidentes que a elas se ligaram, tudo isso deixou-me impressões que se renovam pela vista das plantas herborizadas nesses mesmos locais. Nunca mais verei essas belas paisagens, essas florestas, esses lagos, esses bosquezinhos, esses rochedos, essas montanhas cuja vista sempre tocaram meu coração: mas agora que não posso mais andar por essas felizes regiões, abro meu herbário e logo ele me transporta para lá. 0s fragmentos das plantas que colhi bastam para me lembrar todo esse magnífico espetáculo. Este herbário é para mim um jornal de herborização que mas [sic] faz recomeçar com um novo encanto e produz o efeito de um aparelho de ótica que as pintasse novamente a meus olhos. (ROUSSEAU, 1995, p. 101).

Seu herbário converte-se, então, naquela "porta estreita" que, na velhice, abre-se para a imensidão e o infınito das lembranças felizes. Nesse caso, a memória, sustentada por uma cadeia de miniaturas da floresta, é sofisticada o bastante para reproduzir os sons, as cores e o perfume de um passado distante, e sobretudo a umidade que "vivifica por dentro" um Rousseau velho e ainda "caminhante". Um Rousseau que guarda uma floresta dentro de si e a faz emergir toda vez que abre o seu herbário: mapa de sentimentos cartografados por fragmentos de plantas.

A julgar também por sua "filosofia entre flores”, Rousseau observou e descreveu crianças no rastro dessa mesma poética, pousando sobre elas os seus "olhos que pensam" (associação que deve ser interpretada como uma aliança entre o sensível e o inteligível): "herboriza-a" do ponto de vista biológico, psicológico, epistemológico, moral e estético, sem recusar a graça das individualidades em sua infınita variedade e "que parecem disputar à porfia o direito de fixar nossa atenção” (ROUSSEAU, 1995, p. 93), ou seja, as características individuais de cada criança e seus apelos por reconhecimento e desdobramento dos seus possíveis.

0 jardim vivificado pelos movimentos e chilreios de passarinhos, a expressão literária de seu mimetismo com a superfície que vemos na "Quinta caminhada”, sua paixão por herborizar e desvendar, por uma combinação de lógica e sensação, as pequenas e frágeis estruturas alcançando o gênero de beleza que expressa na "Sétima" parecem mesmo atuar - junto às correntes culturais que as informam - como pulsões vitais e estéticas para a fabricação da moderna e lírica concepção de infância que nos legou.

Não nos esqueçamos que a criança é, para Rousseau, o arquétipo do homem natural passível de reedição na sociedade degenerada, a lembrança nostálgica de um "paraíso perdido", o repouso para sua "fadiga cultural", o "sono da razão", como afirmou no Livro II do Emílio (199, p. 113).

Ao considerar, dentre outras, essa dimensão da infância, Rousseau propõe um problema de ordem filosófico-educacional e pedagógico do mais alto valor: o das tensões entre natureza (criança) e cultura (educação) ou, dito de outra maneira, entre os dois polos, ao mesmo tempo, opostos e complementares, que protagonizam a ação formativa ou pedagógica propriamente dita. Já vimos que o autor resolve esse conflito propondo o conceito-metodologia de "educação negativa" e, para nos esclarecer a respeito, faz uso de categorias estéticas ligadas à discussão sobre o paisagismo de época; ao fazê-lo, transforma conceito e metodologia numa categoria de pensamento-arte que mais inspira do que prescreve.

Aliado a essa energia de ordem estética para fabricar pensamentos, concepções ou conceitos está o anseio de Rousseau pela transparência, em contraposição à máscara ou aos obstáculos que impedem as relações verdadeiras em sociedade.

0 jardim de Júlia, o deslizar do corpo-alma na superfície especular do lago de Bienne, as flores e as crianças são uma experiência da 
"verdade" e, portanto, de repouso. Para o caso dessas últimas, até a perda da inocência,

a infância é definida como o espaço de um jogo inocente numa natureza transparente, sob o olhar benevolente dos deuses: a criança desliza sobre a aparência, revolve a superfície da terra, que não esconde nenhum fundo, e a felicidade desse "jogo artificial" é confirmada pelo olhar dos deuses que não escava nenhum segredo além do visível. (PRADO JÚNIOR, 2008, p. 54).

Pairando sobre paisagens naturais e humanas, demorando-se aqui e ali, a poética que por ora se procurou delinear e associar a Rousseau é, ao mesmo tempo, formativa e formada, uma vez que interpela e se deixa fabricar por aquele que a sente e a pensa.

É dessa poética que extraio, por fım, uma última pergunta: o que as manobras ou meneios operados pelo pensamento-arte de Rousseau, mediante o esmaecimento das fronteiras que procuram delimitar - agora, numa formulação diversa -o filosófico, o estético e o pedagógico, têm ainda a dizer a nós, educadores contemporâneos, que precisamos sofisticar cada vez mais nossas estratégias de acolhimento e condução daqueles que não param de chegar ao mundo?

Talvez devessemos aprofundar a importância já indicada aqui do favorecimento ou proteção do fluxo da experiência infantil. Os cenários dessa experiência podem ser vários, incluídos aí os espaços e tempos cotidianos: da casa, da escola, da rua. Noutras palavras, podem acontecer nos âmbitos privado, intermediário e comum, envolvendo ou não o contato com a natureza. Em certa medida, em cada um desses espaços, nós, adultos e professores, podemos ou não favorecê-la. Por vezes, criando oportunidades pelo arranjo apropriado de coisas e ambientes, mas, na maioria delas, capturando a atmosfera daqueles momentos privilegiados nos quais a criança estabelece um enlace entre o que seus sentidos acusam e a geografia da qual provém esse "o quê": venha ele dos cômodos da casa e do quintal, da sala de aula (ainda que um espaço ligado a objetivos instrucionais bem definidos, não há como impedir ou separar a porção de subjetividades a interagir com seus rituais específicos e aqueles elementos que concorrem para a aprendizagem por canais indiretos, ligados que estão ao sutil âmbito do gosto: o tom de voz da professora, os poucos ou diversos objetos materiais como suportes para “os primeiros exercícios do espírito", as cores e o movimento, a luminosidade, as brincadeiras, o silêncio de "aura comeniana" que compactua com a concentração necessária para aprender conteúdos culturais, enfım, o que circula, sem se fazer notado, pelo tipo de ação que ali se desenrola); ou então do pátio da escola, de um passeio pelas imediações do bairro, de um lugar não conhecido ou ainda e, não raro, de um detalhe, de uma minúcia, das quais as crianças costumam se ocupar por um certo tempo. Mas, mesmo que tenhamos nisso algum grau de intervenção, o fato é que, em muitas dessas vezes, tal enlace acontece à nossa revelia, sem que possamos controlá-lo e, então, deparamo-nos com aquela fração de surpresa que os mais novos sempre reservam para nós. 


\section{Referências}

BACHELARD, Gaston. A poética do espaço. 2. ed. São Paulo: Martins Fontes, 2008. 242 p.

BOSI, Alfredo. A interpretação da obra literária. In: BOSI, Alfredo. Céu, inferno. São Paulo: Ática, 1988. p. 274-287.

ELIAS, Norbert. A peregrinação de Watteau à llha do Amor. Rio de Janeiro: Jorge Zahar, 2005. 71 p.

HAUSER, Arnold. Rococó, classicismo, romantismo. In: HAUSER, Arnold. História social da arte e da literatura. São Paulo: Martins Fontes, 1995. p. 497-726.

MORETTO, Fúlvia Maria Luiza (Trad.). Introdução. In: ROUSSEAU, Jean-Jacques. Júlia ou a nova Heloísa. Campinas: Hucitec: Unicamp, 1994. 659 p.

PESSANHA, José Américo Motta. Platão: as várias faces do amor. In: NOVAES, Adauto (Org.). Os sentidos da paixão. São Paulo: Companhia das Letras, 1995. p. 77-103.

PLATÃO. Diálogos: 0 banquete, Fédon, Sofista, Político. 2. ed. São Paulo: Abril Cultural, 1983. 261 p.

PLATÃO. Diálogos: Mênon, Banquete, Fedro. Rio de Janeiro: Edições de Ouro, 1971. 269 p.

PRADO JÚNIOR, Bento. A retórica de Rousseau. São Paulo: Cosac Naify, 2008. 456 p.

ROUSSEAU, Jean-Jacques. Discurso sobre as ciências e as artes. In: ROUSSEAU, Jean-Jacques. Obras de Jean-Jacques Rousseau: I obras políticas. Direção, introdução e notas de Paul Arbousse-Bastide. Tradução de Lourdes Santos Machado. Revisão crítica e notas acadêmicas de Lourival Gomes Machado. Rio de Janeiro: Globo, 1958. p. 1-37.

ROUSSEAU, Jean-Jacques. Júlia ou a nova Heloísa. Campinas: Hucitec: Unicamp, 1994. 659 p.

ROUSSEAU, Jean-Jacques. Os devaneios do caminhante solitário. Brasília: UNB, 1995. 135 p.

ROUSSEAU, Jean-Jacques. Emílio ou da educação. São Paulo: Martins Fontes, 1999.

STAROBINSKY, Jean. Jean-Jacques Rousseau: a transparência e o obstáculo. São Paulo: Companhia das Letras, 1991. 422 p.

SUASSUNA, Ariano. Iniciação à estética. 11. ed. Rio de Janeiro: José Olympio, 2011. 396 p.

Recebido em: 04.10.2013

Aprovado em: 19.02.2014

Marlene de Souza Dozol é doutora em educação pela Faculdade de Educação da USP (FEUSP), com pós-doutorado no campo da estética, na Faculdade de Filosofia, Letras e Ciências Humanas da mesma instituição (FFLCH-USP) e professora do Centro de Educação da Universidade Federal de Santa Catarina (UFSC). Publicou os livros Da figura do mestre, coedição entre EDUSP e AA, e Rousseau - Educação: a máscara e o rosto, pela Vozes, entre outros ensaios e artigos. 